\title{
Tirnovo (since 1965 "Veliko Tărnovo") From Medieval Bulgarian capital to Turkish Islamic Cultural Centre A general overview
}

\author{
Machiel KIEL
}

\begin{abstract}
Emeritus Professor of Islamic Architecture and Civilization Senior Fellow of the Netherlands Institute in Turkey (NIT)

E.mail: machiel.kiel@googlemail.com
\end{abstract}

\begin{abstract}
Veliko Tărnovo, the former historical city of Tirnovo, today is the capital of a province (Okrăg) in N.E. Bulgaria. Tirnovo is located on the Yantra River and is famously known as the historical capital of the Second Bulgarian Empire. The subject matter research is exploring the history, art and architecture of Tirnovo through ages; and specifically during the Ottoman times (1393-1878), when became an Islamic cultural centre.

Tirnovo grew quickly, between the $12^{\text {th }}$ and $14^{\text {th }}$ centuries, to become the strongest Bulgarian fortification of the Middle Ages, and the most important political, economic, cultural and religious centre of the Second Bulgarian Empire. In the 14th century, as the Byzantine Empire weakened, Tirnovo claimed to be the "Third Rome", based on its influential cultural aspect in Eastern Europe.

This paper discusses the development of population, architecture and cultural of Tirnovo in Ottoman times. It was a flourished centre of Islamic culture, with considerable

examples of almost all known types of ottoman buildings.
\end{abstract}

\section{KEYWORDS}

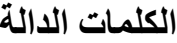

Tirnovo - Veliko Tărnovo - Bulgaria - Ottoman Turkish - Balkan - Islamic.

\section{INTRODUCTION}

The city of Tirnovo of today is the capital of a province (Okrăg) in N.E. Bulgaria which in 2011 had 68.783 inhabitants. The city is situated on the northern slopes of the Balkan Mountains on rocky terrasses formed by a double loop of the capricious river Yantra. Its spectacular setting makes Tirnovo the most romantic and picturesque towns of all Bulgaria. 
Tirnovo has silk, cotton and leather industry and produces much food stuffs and electrotechnical equipment. It has several institutions for higher learning, a HistoricalArchaeological Museum, and since 1962 a University. In Ottoman times (1393-1878), it was the centre of a vast kadılık in the sandjak of Niğbolu, a district which population was fifty-fifty Bulgarian and Turkish. In the 17th and 18th centuries the town itself had a predominant Muslim-Turkish population. With five medreses in the year 1660 and nine in 1790 , it ranked among the most prominent centers of Islamic learning in the Balkans.

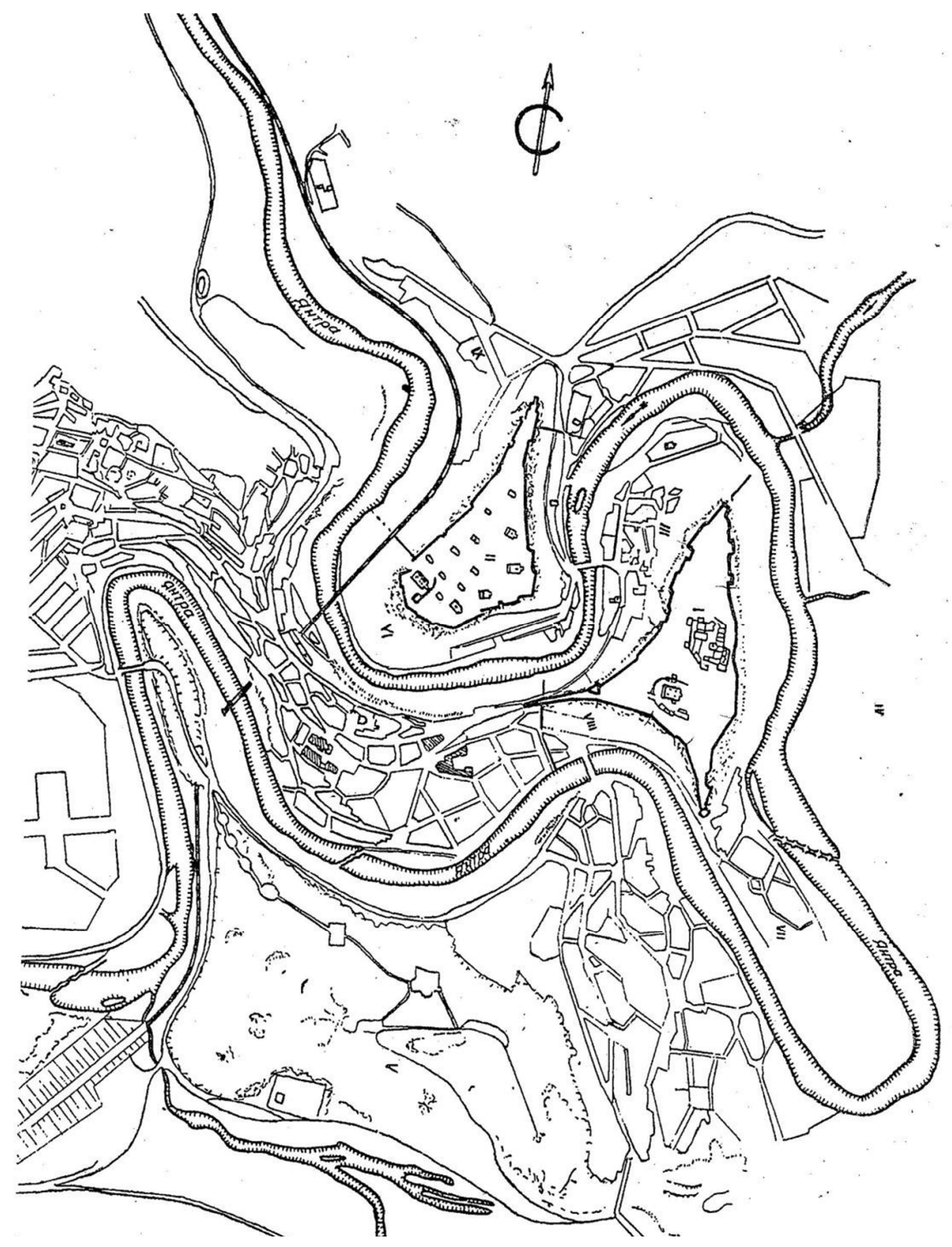

Plan of the medieval city of Tărnovo, drawn by the Škorpil brothers ca. 1900

In the $19^{\text {th }}$ century Tirnovo was made capital of a sandjak in the Eyalet of Silistra. In the local literature about Tirnovo of the second half of the 20th century the pre-Ottoman town was on paper magnified beyond any reality, with the total exclusion of the Ottoman period, transforming it into a "holy place" for an over-exalted Bulgarian nationalism. In the first decade of the $21^{\text {st }}$ century scores of "medieval" buildings were erected on the historic site

- 116 - Tirnovo ... Medieval Bulgarian capital to Turkish Islamic Cultural Centre 
of the Tsarevets Plateau, a kind of Disney land, based on sheer conjecture. It is to this quasi obliterated half of a millennium of history that will be the focus of this overview.

\section{TIRNOVO'S HISTORY THROUGH ARCHAEOLOGICAL EVIDENCES}

The Roman and early Byzantine predecessor of Tirnovo disappeared at beginning of the 7th century as result of the destructive Avaro-Slavic invasions that levelled the entire Roman and Early Christian culture in Bulgaria and its architectural legacy. Early Byzantine coins, found during extensive excavations since 1946, stopped after Emperor Herakleius (610641). In the $8^{\text {th }}$ and $9^{\text {th }}$ centuries a small and humble Early-Bulgarian settlement, a group of hovels, existed on the ruins of the Early Byzantine town. Full life and a monetary culture returned more than 400 years after the destructions of the early $7^{\text {th }}$ century, as is testified by a large number of Byzantine coins beginning with Alexius Comnenos (1080-1118) and continuing in the period of the Second Bulgarian Empire, with coins of the Tsars Todor Svetoslav (1300-1321), Michael Šišman (1323-1330), Ivan Aleksandar (1331-1371) and Ivan Šišman (1371-1393). Next to them came many foreign coins, from the Latin Kingdom of Constantinople, the Byzantine successor states of Nicaea and of Epirus, the merchant Republics of Venice and Dubrovnik (Ragusa), and the Golden Horde in today' southern Russia, showing Tărnovo's commercial network in the $12^{\text {th }}$ to the $14^{\text {th }}$ century. ${ }^{1}$

In the Middle Ages Tirnovo was the capital of the medieval "Second Bulgarian Empire" (Tsarsvo), a great name for a micro-state with a very violent history. Tirnovo as town appeared in the 11th century as a "Fluchtstadt," a refuge, on all sides surrounded by steep and unassailable cliffs formed by the river Yantra. With the palace of the Bulgarian Tsars and the main seat of the Patriarch of the Bulgarian Church and the residences of the leading nobles, it was by far the largest town of Bulgaria and a leading cultural center with a flourishing literary school. ${ }^{2}$ In the existing literature from before 1991 Tirnovo has been magnified to one of the largest cities of Europe. Yet, if we compare Tirnovo with other cities in medieval Europe (which was never done in Bulgaria) and take a look on maps of Cologne, Ghent, Brugge, Florence, Novgorod, Paris, Pskov, etc. or look at maps of Konya, Kayseri or Sivas in Selçuk Anatolia, it immediately shows that in fact it was by far the smallest of all. If we take together the three parts of medieval Tărnovo (Tsarevets, Trapezitsa and the New Town on a narrow strip of land along the river) it can be seen that the build-up surface measured 22-23 hectare. Using the well-known demographic formula of 120 - 150 inhabitants per hectare ${ }^{3}$ this gives a total populating ranging between $2.800-$ 3.400 inhabitants. On Tsarevets hill was much unused space. In the $14^{\text {th }}$ century the city of Cologne within the late $12^{\text {th }}$ century walls (of which large stretches remain preserved, including the proud town gates) covered 403 hectare. Fourteenth century Florence and Bologna were even bigger. Medieval Cologne or Novgorod in Northern Russia had 45.000 inhabitants, Florence and Bologna up to 60.000 !). This brings medieval Tirnovo back to its real size.

A different tool to see medieval Tirnovo in its true size is to compare a number of wellknown and representative Bulgarian churches from the $12^{\text {th }}$ to the end of the $14^{\text {th }}$ century, foundations of the rulers, the Bulgarian Tsars and the top of the ruling class, or rich merchants from the Black Sea ports, with some $12^{\text {th }}-14^{\text {th }}$ centuries village churches in the northern (traditionally backward) Dutch provinces of Groningen and Friesland the real size

\footnotetext{
1 - Dočev, Moneti i obrăštenie v Tărnovo.

2 - Bosilkov, Tărnovo, Xxx.

3 - Mols, Introduction a la Démographie ; Russel, "Die Bevölkerung Europas ...”, pp. 9-57
} 
of Tirnovo becomes clear immediately. Yet this was never done. The same comparison, but with less examples can be done with comparing the size and complexity of the Ottoman provincial hamams with two rare examples of medieval, Bulgarian hamams in Tirnovo. For the churches we can give the following examples, including buildings made by the famous Tsars of the Second Empire, Kaloyan (1197-1207) and Ivan Asen II (1218-1241), as well as three Episcopal churches. Plans and descriptions of these buildings were taken of two standard works, Krăstju Mijatev 1974 and Djurdje Bošković, 1967. ${ }^{4}$ The 14 medieval Bulgarian churches measured together $192,{ }^{27}$ meter in length. This gives an average length of $13,{ }^{76} \mathrm{~m}$. The 14 village churches in Friesland and Groningen measured together $526 \mathrm{~m}$. giving an average length of $37,{ }^{57} \mathrm{~m}$. In other words the village churches in the north of the Netherlands were three times bigger than those in medieval Bulgaria. ${ }^{5}$

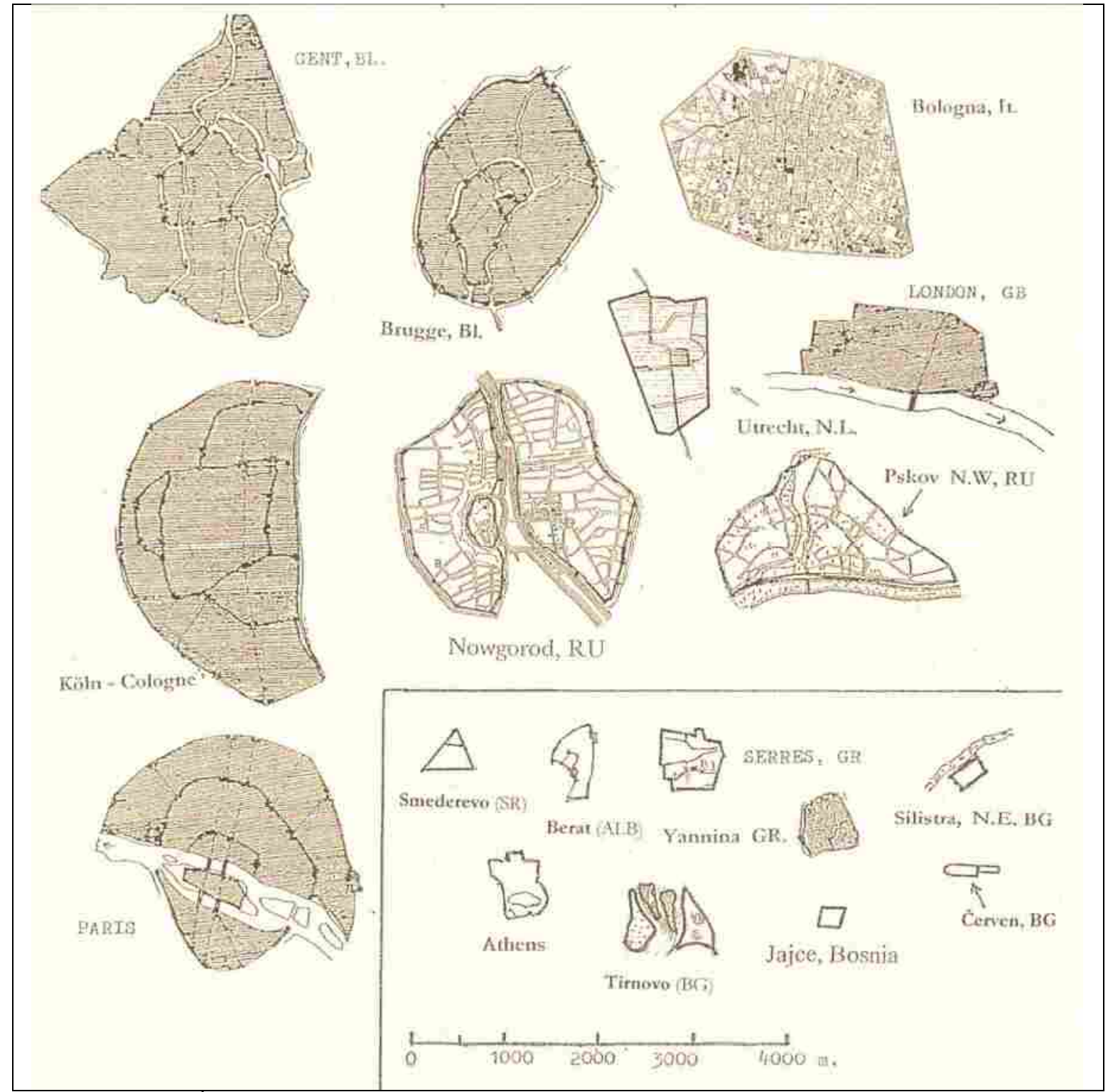

Some $14^{\text {th }}$ century cities in Western and Northern Europe compared with some Byzantin0-Slavic towns in the Balkans. All in the same scale.

\footnotetext{
4 - Bošković, Arhitektura Srednjeg Veka; Mijatev, Die Mittelalterliche Baukunst, pp. 124-144.

5 - For plans and sussinct descriptions of the village churches of the Dutch province of Groningen mentioned here see: Ozinga, Kunstreisboek voor Nederland, pp. 79-115. For the churches of Friesland see: Berg, "Friesland", pp. 5-78.
}

- 118 - Tirnovo ... Medieval Bulgarian capital to Turkish Islamic Cultural Centre 


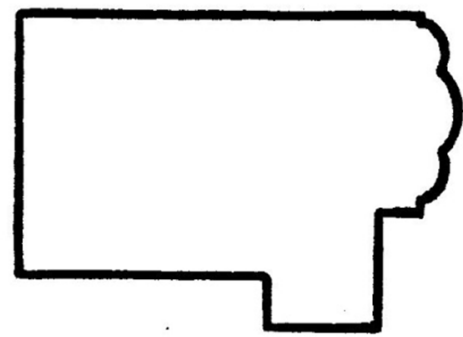

Tărnovo, Patriarch's cathedral of the Assumption of Christ $\left(26^{50} \times 16^{30} \mathrm{~m}\right)$

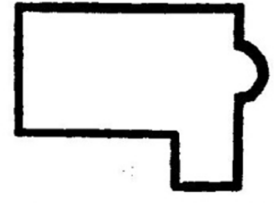

Tărnovo, Peter's and Paul's Cathedral $\left(14 . .^{60} \times 7 .^{80} \mathrm{~m}\right)$

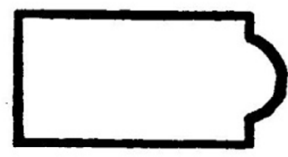

Tărnovo, coronation church of St. Demetrius of Thessaloniki $\left(15 .{ }^{75} \times 8 .^{20} \mathrm{~m}\right)$

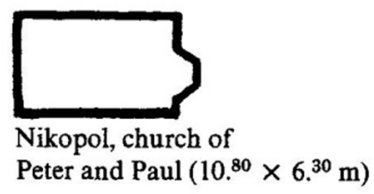

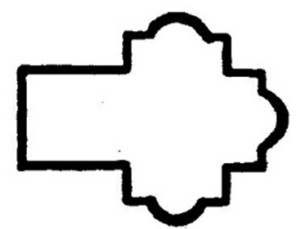

Krupnik, Cathedral $\left(16 . .^{30} \times 12 .^{75} \mathrm{~m}\right)$

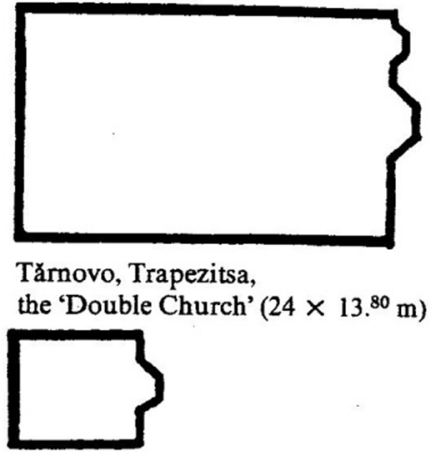

Princely church of Dolna Kamenitsa $\left(8 .{ }^{60} \times 6 .{ }^{60} \mathrm{~m}\right)$

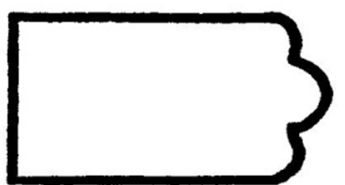

Cerven, Church $\mathrm{N}^{\circ} 2$ $\left(18 .{ }^{80} \times 9 .{ }^{80} \mathrm{~m}\right)$

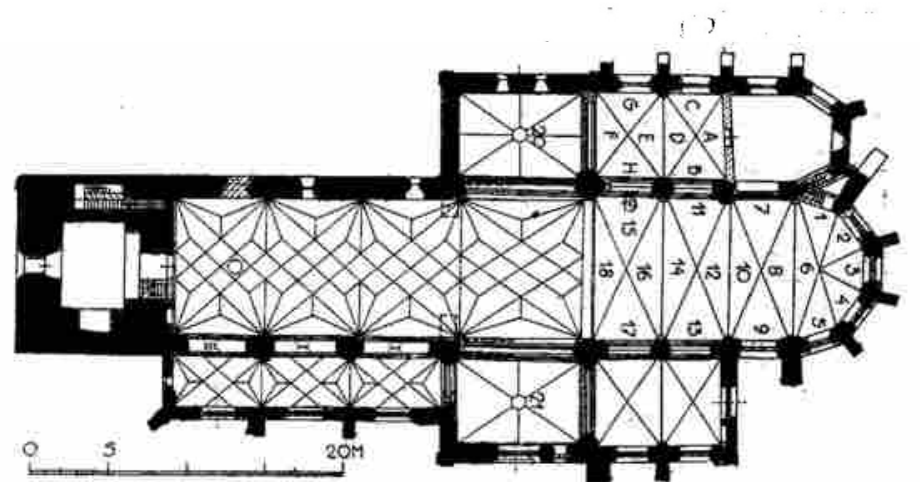

Eight representative examples of Medieval, $\left(13^{\text {th }}-14^{\text {th }}\right.$ cent. $)$, Bulgarian churches compared with the village church of Loppersum in the Dutch province of Groningen $\left(13^{\text {th }}-14^{\text {th }}\right.$ cent.)

\section{All in the same scale.}

In medieval Serbia, with a more elaborated architecture, the situation was almost the same as in Bulgaria. The village church of Loppersum in the province of Groningen the church was $56 \mathrm{~m}$. long. The church of the Episcopal residence, the monastery of žiča, by far the largest medieval church in Serbia, did not get beyond $46 \mathrm{~m}$. including the tower. ${ }^{6}$

\footnotetext{
${ }^{6}$ - Ćurčić, Architecture in the Balkans.
} 
For the hamams we have less material at hand. There are plenty of great and very great $15^{\text {th }}$ to $17^{\text {th }}$ centuries Ottoman hamams still preserved in cities like Skopje or Thessaloniki or Plovdiv/Filibe. In Tirnovo the terribly neglected hamam of Firuz Bey is still standing. Tirnovo is also the place where three very rare medieval hamams have be found during excavations and have been well published. ${ }^{7}$ A comparison of the three medieval Bulgarian hamams and the Ottoman examples in Plovdiv, Skopje, Thessaloniki or Sarajevo shows that the Ottoman examples were four or five times bigger and endlessly more sophisticated than the Tirnovo examples.

In the winter of 1389 Tirnovo surrendered to the Ottoman forces under Grand Vizier Djandarlı Ali Pasha without any struggle, the inhabitants bringing the keys of the town themselves to the Ottoman camp, as they had done in almost all castles and towns of Danubian Bulgaria , as related by Mevlana Neşrî (Neşrî, Unat, Köymen). After a short occupation and after its Tsar Ivan Šišman had again sworn allegiance to ruler, Murad I, Tirnovo was given back to the Bulgarians. Ivan Šišman was a son-in law of the Sultan, which must be one of the reasons why Murad behaved so accommodating. The Šišmanid dynasty, it should be added, was of Kuman/Qipçak Turkish origin which made it possible that the Tsar and the Sultan could directly com-municate. In 1393, however, when Tsar Šišman again (for the third time) broke his word, the new Sultan, Yildırım Bayezid, took the town after a long and violent siege. At that occasion most buildings at Tsarevets Hill were destroyed and a part of the higher nobility was eliminated or banished. The soul of the resistance, the Head of the Bulgarian Church, Patriarch Evtimi, was treated with great honor by the Sultan and given back a church which he could use as center of the Bulgarian Church. Later, when the Sultan had returned home the Turkish commander of Tirnovo judged it safer to banish the Patriarch to a monastery in the south of the country, presumably Bačkovo, south of Philippople (today's Plovdiv) where he died a decade later. A part of the population of Tirnovo was deported and Greek, as well as Turkish settlers were colonized in the town. Yildirım installed a small garrison in the Tsarevets castle, converted the Patriarch's church on Tsarevets hill into mosque and had a zaviye (later medrese) built in the town. Many Bulgarian artists, church leaders and writers, jobless because of the disappearance of the royal court and the nobility, left the town, fled or emigrated across the Danube and contributed greatly to the development of architecture, literature and painting of the young, Christian, principality of Walachia. ${ }^{8}$

In the existing Bulgarian historiography it is maintained that after the conquest the Ottomans pursued a ruthless and systematic policy to destroy all that remembered on the medieval glory of Bulgaria and aimed at the destruction of the "Bulgarian national identity." However, the Church of St. Demetrius, where in 1185 the Second Bulgarian Empire had been proclaimed, and the monastery Church of the Forty Martyrs on the Yantra, built in 1230 by the great Tsar Ivan Asen II to commemorate the Bulgarian victory over the Byzantines at Klokotnitsa, survive until this day, including the historically highly important $9^{\text {th }}$ and $13^{\text {th }}$ century inscriptions on the pillars of the interior of this church, forming a kind of res gestae of the pagan Khan Krum (803-814), Khan Omurtag (815-831) and the Christian Tsar Asen II (1218-1241). According to generations of Bulgarian historiographers this monastery church was taken over by Y1ldırım Bayezid and

\footnotetext{
7 - Dermendžiev, “Dvortsovata banya ...”, pp. 124-141; Dermendžiev, "Novoodkrita banya ...”, pp. $77-100$. 8 - Turdeanu, La litterature bulgare.
}

- 120 - $\quad$ Tirnovo ... Medieval Bulgarian capital to Turkish Islamic Cultural Centre 
transformed into the Kavak Baba Tekkesi. Recent research by young and promishing Bulgarian scholars proved to be wholly unfounded. ${ }^{9}$

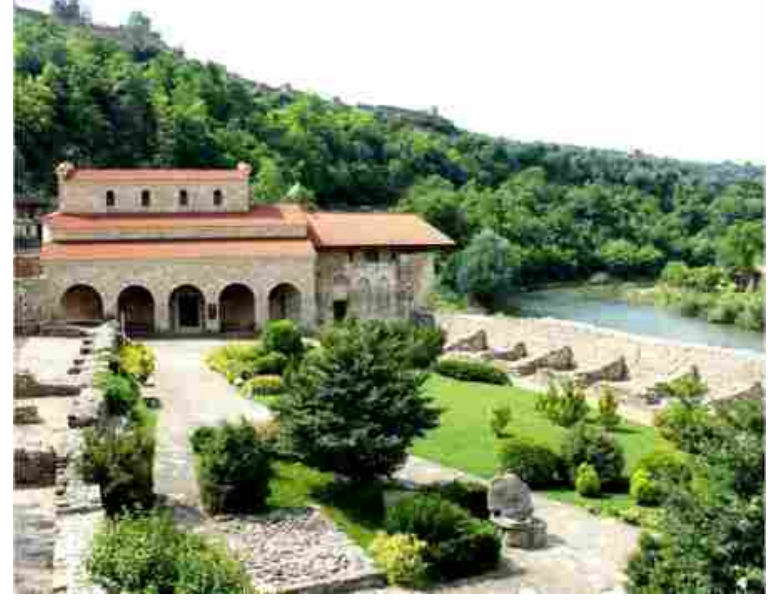

Tirnovo, Monastery of the Forty Martys, symbol of the Victory of Klokodnitsa, 1230

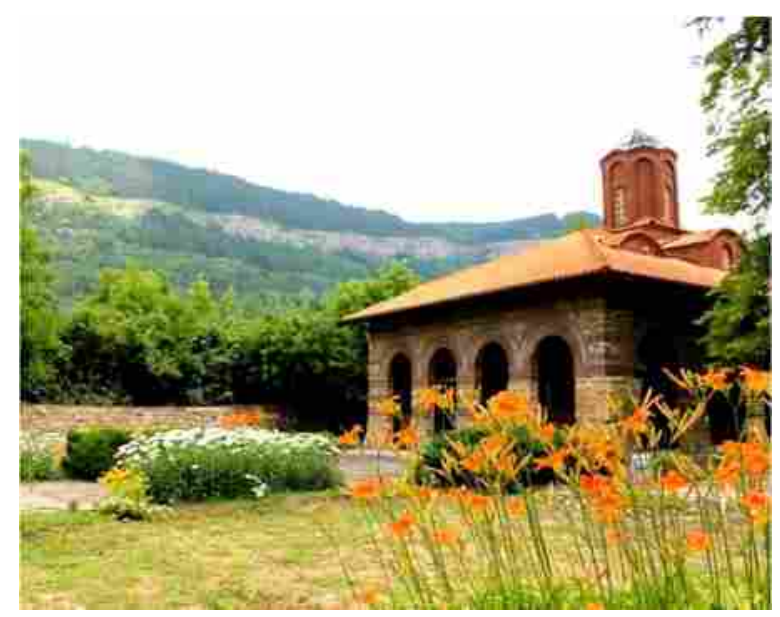

Tirnovo," Cathedral" of Peter and Paul built by Tsar Kaloyan (1197-1207) to commemorate his coronation and International recognition

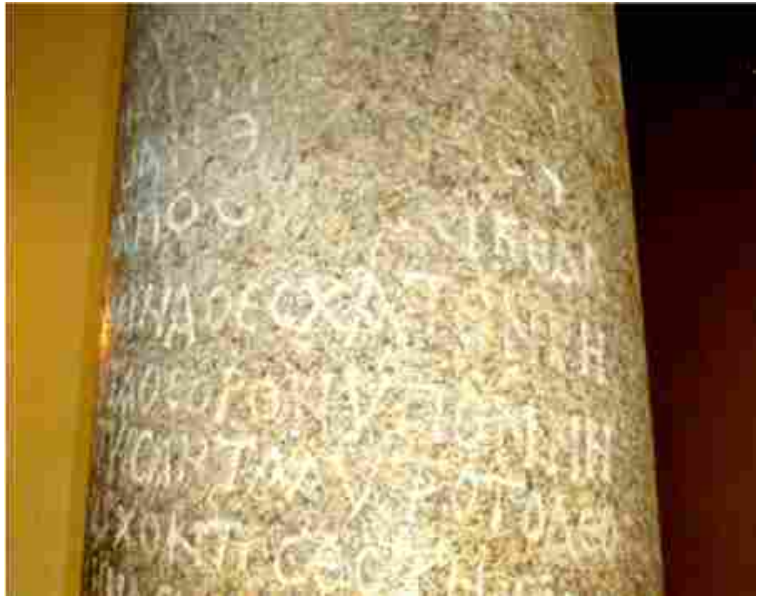

Church of the Forty Martyrs, column with Greek inscription of Khan Omurtag, A.D. $814-831$

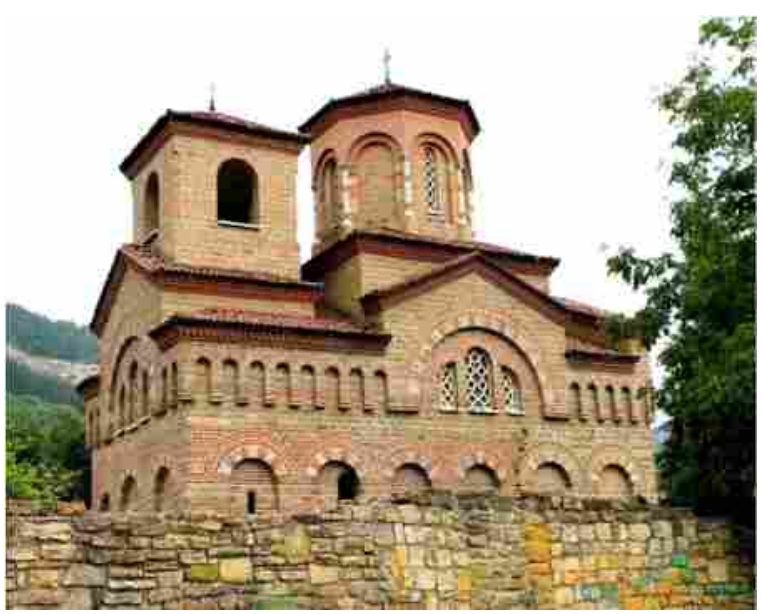

Tirnovo, Church of St. Demetrius, where in 1185 the Second Bulgarian Empire was proclaimed

The church of Sts. Peter and Paul, originally built by the mighty Tsar Kaloyan (1197-1207) to commemorate his crowning and international recognition, also survived. This church had been given by Sultan to Patriarch Evtimi to serve as cathedral, as said. It remained in Christian hands until the end of the Ottoman period. This church was refurbished in the early $15^{\text {th }}$ century and was painted anew with frescos of the highest quality of all Bulgarian art. All but one of the Bulgarian specialists agreed on a date in the early $15^{\text {th }}$ century thus only some years after the Ottoman conquest. Yet none of them mentions the implications this has for the theory that the Ottomans tried to "destroy the Bulgarian national identity" which had become a dogma of the Party line of how Bulgarian history had to be. The church of St. Demetrius, as well as St. Georg built by Tsar Ivan Aleksandar, remained in the hands of the Christians; the church of the Forty Martyrs until the end of the 18th century when it was abandoned. If the Ottoman campaign to exterminate Bulgarian culture

9 - Genova, “Ošte vednăž za tsărkvata ...”, pp. 451 -458; Părveva, “Zaviyeto Kavak ...”, pp. 324 -408. 
and identity had really existed it is little likely that these highly valuable national symbols would have survived. In the same line lies the findings of the best specialist on the art of the illuminated Bulgarian book, Aksinia Džurova (daughter of the powerful General Džurov), who saw no break in the quality and production of the illustrated book between the $14^{\text {th }}$ and $15^{\text {th }}$ centuries, of which Tirnovo was one of the main centers. ${ }^{10}$

In the first half of the $15^{\text {th }}$ century, Tirnovo started to recover and took on the features of an Islamic town. This process was greatly pushed by one of the powerful governor from the time of Murad II, Firuz Bey who in 1435/36 built an elegant domed mosque, two mescids, an imaret for the poor, a medrese, a mektep, a hamam, a caravansaray, a bridge over the Yantra, and a number of shops and water mills. ${ }^{11}$ A new exclusively Muslim center developed around these buildings.

The new upswing was briefly interrupted in 1444, when a part of the Crusaders army attacked Tirnovo and captured and destroyed the castles in the surroundings. Tsarevets Castle, the core of the medieval town, could not be taken. The eye witness Hans Mehrgast, mentions that King Vladislav had send a detachment of 500 men "to plunder and pillage Tirnov," but this detachment was largely destroyed by the Turkish defenders. The likewise contemporary Gazavat-i Sultan Murad Han notes that the King had given order that "the castle of Tirnovo must be besieged and conquered mercilessly," and dispatched two detachments that could not take the town. ${ }^{12}$ From 1444 onward the Tirnovo lived through a period of more than a century and a half of peace and prosperity in which the town greatly developed

The Ottoman population and taxation registers of 1479, 1516, 1540 and 1580 allow us to see how the town developed. In 1540 Tirnovo had 11 Muslim mahalles with five mosques, six mescids, an imaret, and the Zaviye of Kavak Baba, the latter also having an imaret distributing free food to the travellers and the poor. There were 270 Muslim households and 309 households of Christians, and 18 households of the merchants of Dubrovnik.

The register, from 1579, shows that both communities of the town had grown further to a total of 714 households, of whom 41\% was Muslim. In 1640 the Catholic Bishop Bakčić mentions that Tirnovo had 2000 houses of Orthodox Christians, who spoke Greek and Bulgarian and numbered 10.000 souls. They had eight churches and one monastery at their disposal. Next to them were 2000 Turkish houses with more than 10.000 inhabitants. The Turks had seven great mosques. Bakčić' numbers of people are highly exaggerated but do reflect the composition of the town's population (fifty-fifty Muslim-Christian).

In 1659, Philip Stanislavov Catholic Bishop of Nikopol, visited "Tarnovium Civitas". He noted that it was the seat of an archbishopric of the Orthodox Church, with an episcopal church and three other Orthodox churches, besides one Catholic Church. The number of houses of "Bulgarian schismatics" was 700, the Catholics had only 17 houses. They were merchants from Dubrovnik. The Turks numbered 3000 (650 households) and they had seven mosques. ${ }^{13}$

10 - Džurova, 1000 Godini Bălgarska, p. 67, 109. When the writer of this paper asked Džurova in person, she said: "Yes, this was the situation. The rest does not interest me."

11 - Bistra A. Cvetkova - A. Razbojnikov (eds.), Izvori za Bâlgarskata Istoriya, III,

12 - İnalcık - Oğuz, Gazavât-ı Sultân Murâd, p. 46/47.

13 - Fermendžiu, Acta Bulgariae Ecclesiastica, p. 262/63

- 122 - Tirnovo ... Medieval Bulgarian capital to Turkish Islamic Cultural Centre 


\section{NEW SATELLITE-TOWNS AND BOROUGHS AROUND TIRNOVO (16-19 ${ }^{\mathrm{TH}}$ CENTURIES):}

\section{Arbanassi}

There are some indications for the cultural life of the Christian population of Tirnova (new and high-quality fresco paintings in the church of St. Georg and in the Cathedral of Sts Peter and Paul), but this is completely overshadowed by the spectacular growth of the satellite town of Arbanassi (Arnautköy for the Ottomans) on the plateau, a few $\mathrm{km}$ from Tirnovo, where Christian art flourished abundantly. In the current Bulgarian historiography this formerly rich kasaba was settled by Bulgarians coming from Albania, and is held to have been the summer residence of the Bulgarian Tsars. This imperial property was then taken over directly by the Sultan as his hass. Besides fantasy there are no sources to support this view. In fact Arnautköy was formed shortly before 1500 by a small group of settlers from Albania. The tahrir of 1516 mentions it as a newly founded village of 9 houses, its inhabitants having good Albanian names, not Bulgarian. After having been mülk property of three successive owners the village was acquired by the Grand Vizier Rüstem Pasha, who brought in many new settlers from southern Albania. According to a Mülk and Vakf Defter from 1540, ${ }^{14}$ Arnautköy numbered 63 households, inhabited with people with specific Albanian names: Ando, Duka, Gjin, Gjon, Leka, Lepur, Miho etc. Rüstem Pasha secured a very privileged status for the village giving it a derbenci status and then made it $v a k f$ property for his many foundations elsewhere. The effect of the changed status and the protection of the vakf system are reflected in the population numbers. In 1540 it had 63 hâne, in 1570: 271, and in 1642408 hâne. In 1691, after the Cizye reform, it had 1.145 adult males, or about 790 households. ${ }^{15}$ In 1770 it is reported to have had 1000 houses. By then it was the summer residence of the bishops of Tirnovo, Lofça and Rusçuk and representatives of the famous St. Catherina Monastery on Mount Sinai in Egypt. Moreover, members of some of the richest and most influential boyar families from Valachia, the the Brănkoveanu, Cantacusino and Filipescu resided in Arnaudköy. The merchants of Arnavudköy traded with Italy, Poland, Hungary and Russia. ${ }^{16}$ In 1798, during the decade of anarchy following the Russo-Turkish War of 1788/92, Arnaudköy was plundered and half destroyed by the Kircall rebels. It never recovered. In 1873 it had only 93 households. Today six churches and two monasteries, built and repeatedly enlarged between the 16th and 18th century, are still preserved; as do many rich old houses and mansions. All the churches have rich fresco paintings, made by the best artists of Bulgaria of that time. Among them was the church of St. George that in 1561 was painted by Nikolla, son of Onufri, the most famous painter of Albania born near the central Albanian town of Elbasan who left number of painted church interiors, in his native village of Shelcan, in the church of St. Venerande in Valsh in the same area, in the town of Berat, in the Monastery of Zrze in the Republic of Macedonia and in the churches of the Sts. Cosmas and Damian and the church of the twelve Apostles both in Kastoria in Northern Greece. Besides that Onufre and his son left numerous icons behind, belonging to the best of the Balkans. ${ }^{17}$

\footnotetext{
14 - Sofia, National Library, Oriental Department, O.A.K. 217/8.

15 - Sofia, National Library, Oriental Department, O.A.K. 13/60.

16 - Jireček, Das Fürstenthum Bulgarien, p. 458.

17 - Çika -Drishti, The Icons of Berat, p. 86/87. It is a magnificent book of 101 pages with the best possible color plates and text of highest scientific level.
} 


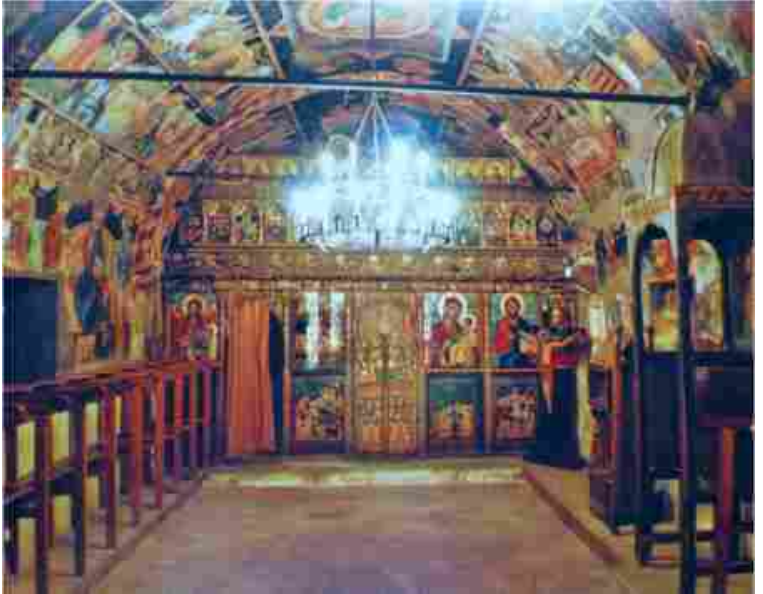

Tirnovo, suburb Arbanassi, interior of the church of the Nativity of the Virgin Mary

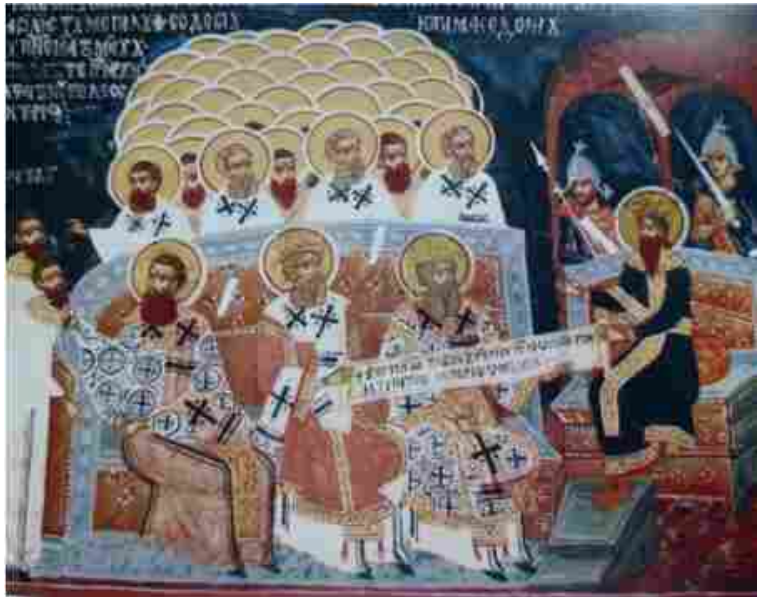

Tirnovo, Arbanassi. Nativity Church, depicting the First Counsil of Nicaea

\section{Kilifarevo}

The village of Kilifarevo, just south of Tirnova, rose from 33 hâne in 1516 to 256 in 1642 and 918 in 1873. In the last quarter of the 16th century it became part of the rich vakf for the türbe of Sultan Selim II (later also of Murad III and Mehmed III) in Istanbul and got a privileged status.

In the immediate neighborhood of Tirnovo and Kilifarevo are three large monasteries, Kilifarevski, Preobraženski and Sveta Troitsa. They were rebuilt in the Ottoman period, constituting important centers of Bulgarian culture and literature.

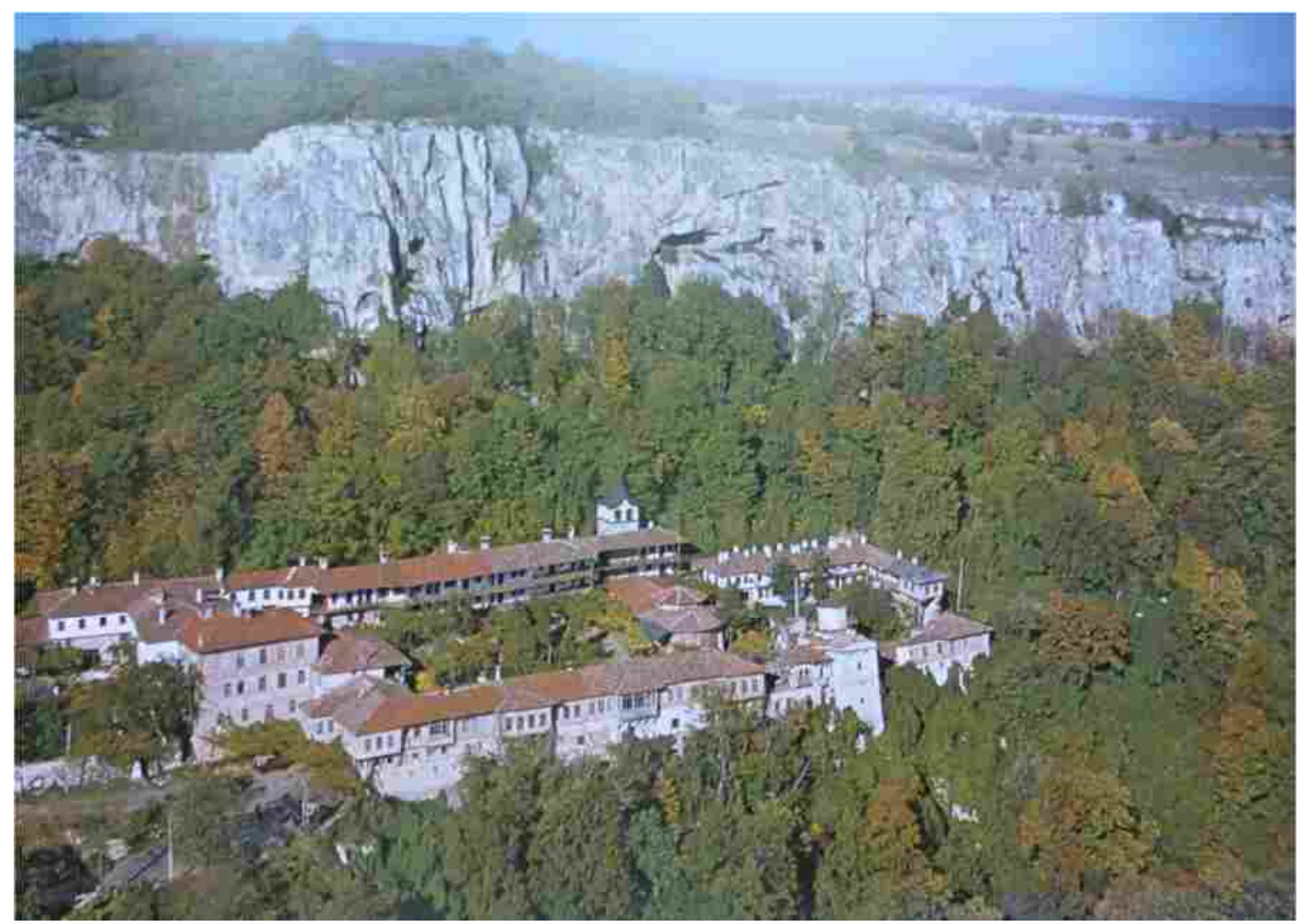

Kilifarevo Monastery near Tirnovo, 14th century, restored in 1705

- 124 - Tirnovo ... Medieval Bulgarian capital to Turkish Islamic Cultural Centre 


\section{Trjavna}

The emergence and development of town of Trjavna is a good example of a town that rose ex nihilo. It was founded in April 1565 by Sultanic order after a proposal of the local authorities from the district ${ }^{18}$ Trjavna started as a derbend village guarding the difficult pass road over the Balkan Mountains to the plain of Thrace and further on to Edirne and Istanbul. Before its foundation it was "an empty and unguarded place." The 1579/80 tahrir mentions Trjavna with 40 hâne. Like Kilifarevo it was included in the Türbe, of Sultan Selim II, Vakf, got a still better status, and saw a similar rapid expansion. In 1607 it had 132 households and in 1647 341. In half a century it had thus grown from 200 inhabitants to $1.700 .{ }^{19}$ At the end of the Ottoman period the Salnâme of the Vilayet of the Danube from 1873 shows it with 2.420 inhabitants. It had a large church of the Archangels and many rich and well-built houses of which a number of them remains preserved. Under Bulgarian rule after 1878 Trjavna stagnated like most of the small mountain towns and in 1934 it had only 2.933 inhabitants. $^{20}$

\section{Drjanovo}

The little town of Drjanovo, $24 \mathrm{~km} \mathrm{S.W}$. of Tirnovo is a good example of a settlement that was pushed up by a change of its status by the Ottoman authorities and became a prosperous town. The place where Drjanovo developed was settled since the second millennium B.C. as revealed by archaeological finds. As a permanent settlement it is first mentioned in a large fragment of an Ottoman tahrir which as O.A.K. 45/29 is preserved in the Sofia National Library and was published by Nikolaj Todorov and Boris Nedkov in 1966. The fragment is dated by internal evidence either in $1479 / 89^{21}$ or end $1480 \mathrm{~s}$ beginning $1490 \mathrm{~s}^{22}$ In our source Drjanovo is mentioned as a village with 83 Christian households and two widows, and total tax revenue of 7.345 akçe (small silvercoin within 1481, 47 Akçe in one Venetian gold coin). This means that the village household paid 88 Akçe per year. The village was part of the timar of the Kadı of Tirnovo.

The next step is shown by the tahrir defter T.D. 167, preserved in the B.O.A. in Istanbul, written in 1530 on the basis of a register from 1521. In last mentioned year Drjanovo was the "property of the vakf of the late Kasim Pasha" for his foundations in Edirne/Adrianople, a mosque, dervish convent, hamam and soup kitchen (imaret) on the banks of the Tundja River, a branch of the great river of Thrace, the Maritsa (or Meriç in Turkish). Besides these buildings Kasım Pasha had built a mesdjid and a mu'allim-hâne (primary school) in the town of Tirnovo. From all these building only the mosque, a sturdy single domed building still stands. The Arabic building inscription above the main entrance gives the year in which it was completed, 883 (4 April 1478 - 24 March 1479 A.D.) Evliya Kasım Pasha (as he was known locally) died in the same year. The inscription on his tomb stone gives the same years as the mosque. ${ }^{23}$

\footnotetext{
18 - İstanbul, Başbakanlık Osmanlı Arşivi (=B.O.A) Mühimme Defter No 6, p. 453.

19 - Kiel, "Zur Gründung und Frühgeschichte der Stadt Trjavna in Bulgarien...", pp. 191-218.

20 - Čankov, Geografski Rečnik, pp. 464 -466.

21 - Dimitrov, “Za datirovka na njakoj ...", p. 244.

22 - Cvetkova, "Sur le sort de Tărnovo", p.182.

23 - Bayrakal, Edirne'deki tek kubbeli camiler, pp. 72-76 \& photographs 51-54. See also Ayverdi, Osmanl Mimarî sinde Fatih Devri, pp. 268-269, pictures: 431-452.
} 
Drjanovo had made a great jump forward, caused by the special status it had received when becoming part of an important mosque. It now had one Muslim household, 224 Christian households and 219 unmarried adult males (mücerred). The latter number is very high and points to a young population. From the 224 households 60 households got the status Derbenci, armed warden of the passes over the Balkan Mountains who had received a very privileged status. The other households were also privileged.

From the year 1540 we have another detailed source, a large fragment of a mufassal defter of the vakfs and mülk properties in Northern Bulgaria: O.A.K. 217/8 in the Sofia National Library. ${ }^{24}$ There were now five Muslim households in Drjanovo, all five recent converts. The bulk of the population was made up of 243 Christian households and 193 mücerreds, altogether between 1.200-1300 inhabitants. The 60 Derdendžis were still present together with their privileged status. The register also mentioned that there were a number of fermans from the time of Sultan Bayezid II (1481-1512) listing the privileged status. The total revenue of the place was 52.332 Akçe or 211 Akçe per household. This does not point to in increased exploitation but to a strong expansion of the village economy. The Drjanovo economy rested on a very great wine production and highly developed sheep breeding. The tax on sheep of the villages was 4.560 Akçe. In the $16^{\text {th }}$ century the standard tax was one Akçe per two sheep. This gives a total number of 9.120 sheep, or 37 animals per family. This is very high. From 50 á 60 sheep a family of five could live. The kanun-nâme of the village noted stipulated that from 50 sheep 15 akçe was taken as tax. The same source makes clear that the harac of normaly 50 akçe per adult male was not taken. Instead of 50 akçe 25 was taken.. The ispence tax of 25 akçe was not taken at all. Moreover the mücerreds did not pay the harac. The other pillar of the village' economy was a very large wine production which was also taxed. The sum of 25.280 akçe was taken as wine tax but the mentioned sum also included the niyabet. The amount taken as niyabet is not given. All these elements made Drjanovo an interesting place to settle down, which at once explains how the population jumped up so quickly.

The Salnâme of the Tuna (Danube) Vilayet of 1873 mentions in Drjanovo 69 Muslim house-holds with 336 inhabitants (gives 4,9 inh. per household) and 543 Christian households with 2.848 inhabitants (5,2 per Housh.) and a total of 3184 inhabitants. In the first half a century of Bulgaria as an independent state Drjanovo, like most of the small mountain towns, declined or stagnated. After 1878 three quarters of the Muslims immigrated to Turkish territory. In 1887 (the first Bulgarian census) the population stood at 3.196 Bulgarians, the Turks at 101. By 1934 it had sunk from 3.300 to 2.820. In that year the geographer Žečo Čankov remarks that: "In the Turkish period the little town was the center of a lively trade and crafts but after the liberation it declined." Previously it had a highly developed production of fur coats, silk making, the production of stout woolen cloth (abadžjstvo) and raw silk which was exported to Tsarigrad (Constantinople), Shkoder in Albania and Italy as far as Milano.

In the second half of the $20^{\text {th }}$ century Drjanovo started to grow again, made possible by a modest industrialization. The Bulgarian census of 2015 registered 7.968 people. In the town still are three great churches, all built in the Ottoman period. One of them, the church of St. Nikolas, is the work of famous $19^{\text {th }}$ century architect Nikola Fičev, a son of Drjanovo.

${ }^{24}$ - Published by Bistra Cvetkova in 1972 in: Turski Izvori vol. III, pp. 437-440

- 126 - Tirnovo ... Medieval Bulgarian capital to Turkish Islamic Cultural Centre 
All these places played an important role as cultural centers, all having a number of churches, monasteries, or fine old mansions, but none as well preserved as those in Arbanassi.

\section{Tirnovo}

The 1691 register is the first to show Armenian settlers in Tirnovo, 13 nefer, mostly merchants. Their community grew and was soon to have its own church and cemetery.

In 1710 an entirely new tahrir defter was made of the property of the vakf of Gülnuş Ümmetullah, mother of Ahmed III. This rich vakf included the town of Tirnovo, then having 506 Muslim households and 411 households of Christians. The town had about 3.200 inhabitants, 55\% being Muslim.

Most of the 18th century meant a great upsurge for Tirnovo. The mufassal Avariz Defter K.K. 2813 from 1164 (1751) shows this. The town now had 14 Muslim mahalles with 886 households and seven mahalles of Christians with 314 households. The number of inhabitants rose to 5.700 of whom three quarter were Muslims. The 18th century also saw the introduction of silk culture in Tirnovo and its district. The 1710 register also shows that wine production was the pillar of the economy of the town, followed by the income from its market function (bac-i bazar). Shortly before 1178 (1765) Ali Efendi founded in Tirnova a new library, an indicator of expanding Muslim learning in the town. ${ }^{25}$

At the end of the $18^{\text {th }}$ century the famous old church of the Forty Martyrs fell in disuse and was converted into a zaviye. A document of $1851^{26}$ shows that it was than functioning as a zaviye for the Halveti dervishes.

Around the year 1800 Hadji Ali Ağa erected in the center of the Turkish part of the town a monumental domed and lead-covered mosque (the Kurşunlu Cami) accompanied by a medrese with seven fountains in its courtyard and a rich library in a separate building covered by two domes. The architectural beauty of the complex was praised by the widely travelled geographer-scholar Felix Kanitz. In the 19th century, the town expanded at an even greater speed and reached an extraordinary prosperity. In 1836 the French geographer Ami Boué estimated 12.000 inhabitants.

The Salname of the Tuna Vilayet from 1286 (1869/70) describes Tirnovo as capital of a sandjak with 453 villages. The town consisted of 3.091 houses and had 21 mosques, 14 churches, nine medreses, four tekkes, three hamams, and 1.056 shops. The town now had a population of about 15.000 , which for $45 \%$ was Muslim.

During the disastrous "doksanüç harbl," on June 24 of 1877, Russian troops took Tirnovo. The greater part of the Turkish population fled, leading to decline and stagnation in spite of the influx of many Bulgarian settlers from the mountain villages. In 1887 Tirnovo had sunk to 11.314 inhabitants of whom only 688 were Turks. In 1895 the Kurşunlu Cami complex was demolished. The rich collection of books of its library disappeared without leaving a trace. It took more than half a century before the town recovered from what usually is called "liberation" (1934 13.963 inhabitants).

25 - Istanbul B.O.A., Cevdet Maarif No 402.

26 - Cevdet Evkaf. 


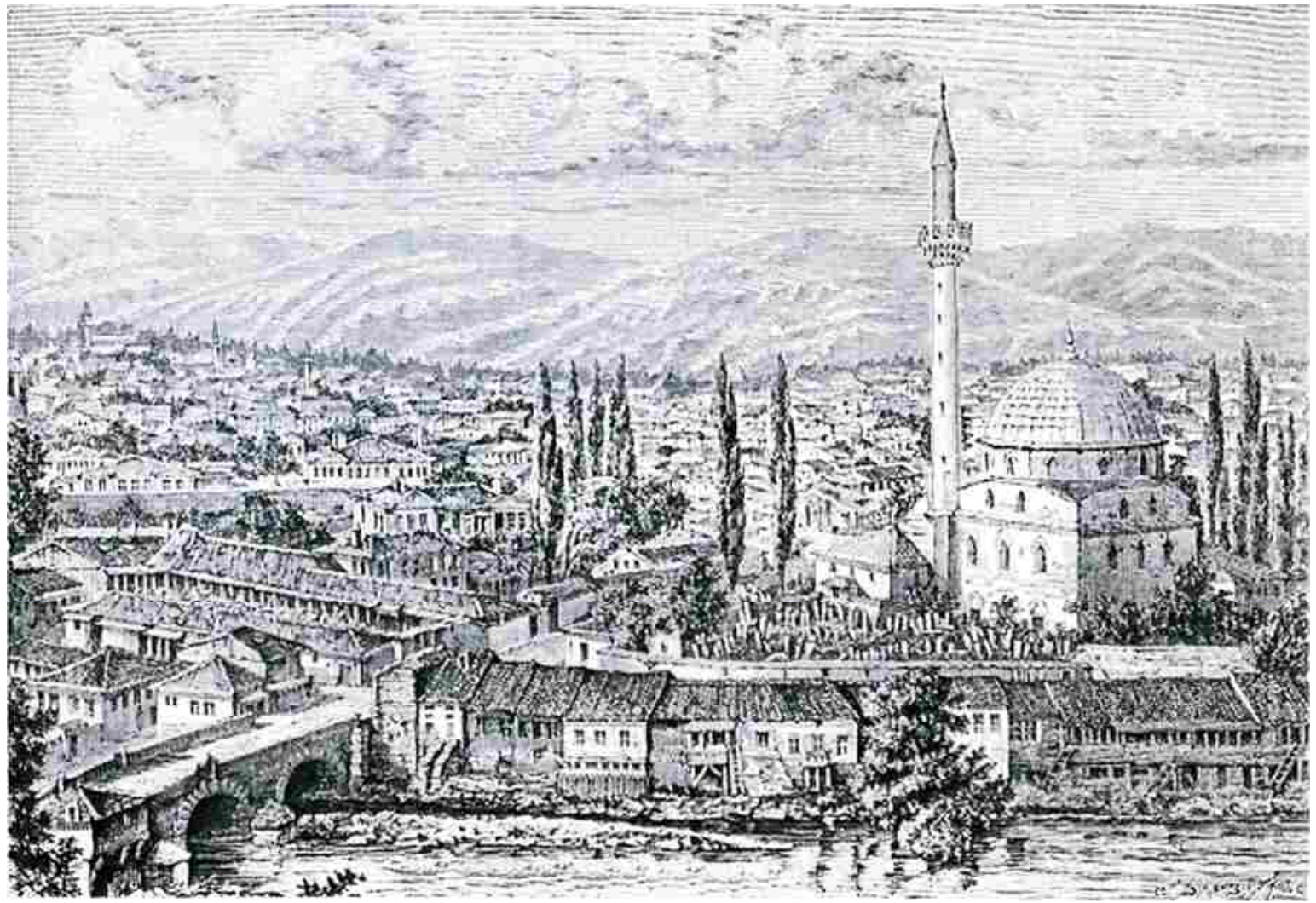

Panorama of late-Ottoman Tirnovo.

In the foreground the Mosque of Hadji Ali Agha,

(also known as Kursunlu Camii, built around the year 1800)

Drawing by Felix Kanitz in the early 1870s.

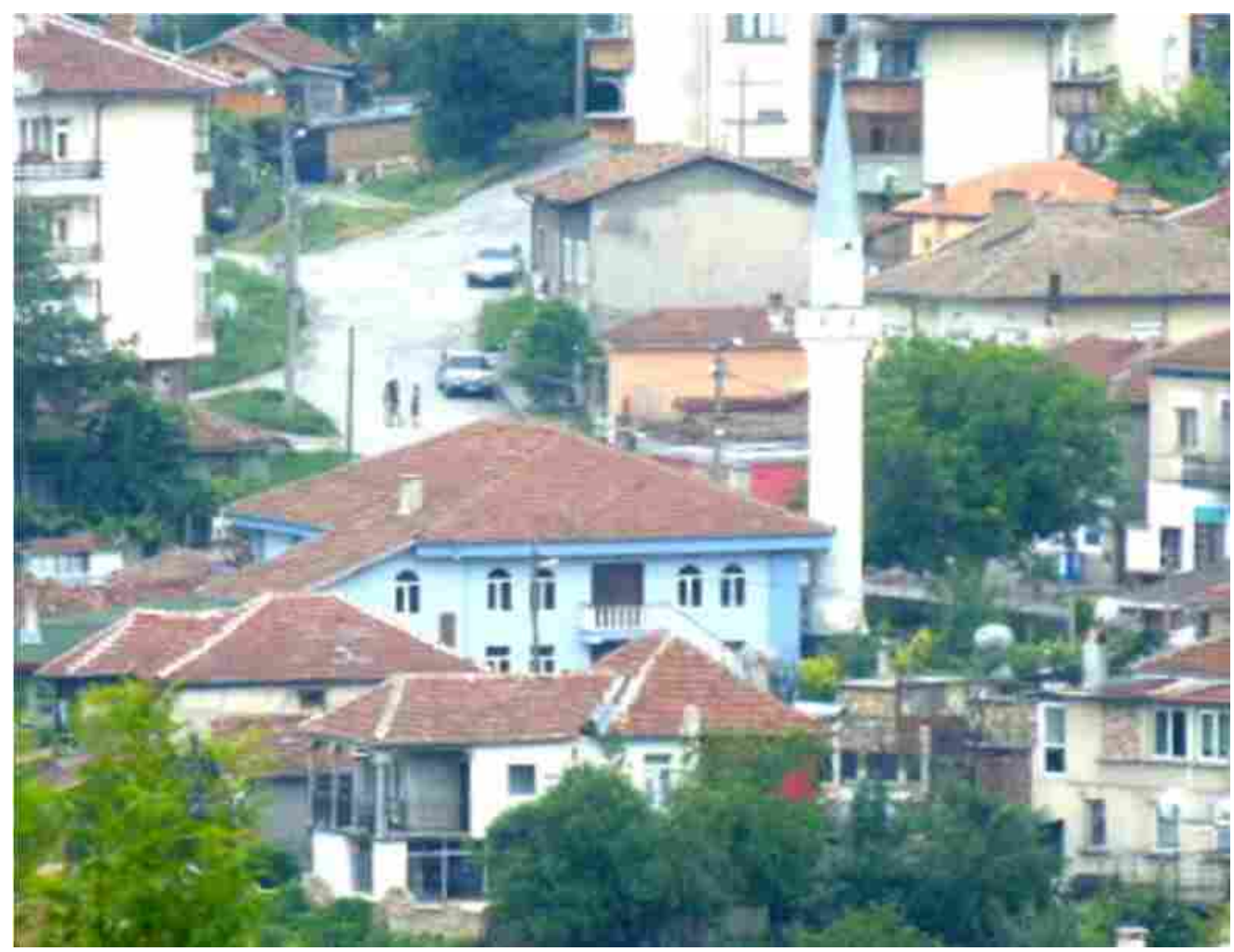

Tirnovo, the last mosque, built after the fall of the communist regime

- 128 - Tirnovo ... Medieval Bulgarian capital to Turkish Islamic Cultural Centre 
In 1913 a terrible earthquake destroyed or badly damaged many historical buildings. Most of the damaged mosques were demolished, the medieval churches St. Demetrius and Sts. Peter and Paul, with their outstanding fresco decoration were left to rot away more than half a century before a crude kind of restoration and save-guarding began.

Especially after 1960 old Tirnovo saw vast archaeological excavations, combined with very bad quality "restoration work" or crude reconstruction of the medieval ruins, turning Tsarevets Hill into a "medieval Disney-land" and holy place of Bulgarian nationalism. The Ottoman heritage, which did not fit with the ideological nationalism of that time, was entirely neglected. Its remains were completely obliterated and also fully ignored in publications.

Only since the late 1990s young Bulgarian Orientalists published a number of important studies on the Islamic spiritual life of the town. ${ }^{27}$ As late as 2007, two Arabic manuscripts of the destroyed library of Ali Ağa in Tirnovo were found in libraries in Moscow. ${ }^{28} \mathrm{~A}$ humble and small mosque in the former outskirts of the town, built of wood and mud brick (kerpiç), survived till the beginning of the $21^{\text {st }}$ century, serving Tirnovo's minor MuslimTurkish community. In the most recent years the humble building was replace by a much larger mosque with a high minaret visible from afar. A detailed plan of the town, drawn in 1910 by the Czech archaeologist Karel Škorpil, shows Tirnovo's complicated layout with its mosques, churches and synagogues, and the cemeteries of the four religious communities of the town, Islamic, Orthodox, Armenian and Jewish, and keeps alive the memory of the multi-cultural and multi-lingual make-up of the town and preserved the historical toponyms, now all obliterated. ${ }^{29}$

What we can see in Tirnovo today are its medieval and Ottoman time churches, the Disneyland castle of Tsarevets and the fake cathedral, but especially the spectacular setting of the town and its many $19^{\text {th }}$ century houses and the churches of Arbanassi with their magnificent and elaborated $16^{\text {th }}-18^{\text {th }}$ centuries fresco paintings.

Tirnovo was the birth place of the late-Ottoman poet, musician and writer of 12 culturalhistorical works İsmail Fenni Bey Ertogrul (1855-1946). Fenni is also the translator of the works of Hegel, Oliver Lodge, Stuard Mill and Montaigne. He is remembered as Turkey's greatest philosopher. ${ }^{30}$

\footnotetext{
27 - Genova, “Ošte vednăž za tsărkvata ...”, pp. 451 -458 ; Mutafova, "Središte na Islamskiya ...”, pp. 409 450 ; Părveva, “Zaviyeto Kavak ...”, pp. $324-408$.

28 - Zajčev, "Dva Arapski rukopisi is Tărnovo ...,", pp. 420-423.

29 - Škorpil, "Plan na starata bălgarska ...", pp. 120 -146.

30 - İnal, Son Asır Türk Şairları, pp.393 -395 ; T.D.E. Ansikl., p. 81/82.
} 


\section{REFERENCES}

- Sofia, National Library, Oriental Department, O.A.K. 13/60.

- Sofia, National Library, Oriental Department, O.A.K. 217/8.

- İstanbul, Başbakanlık Osmanlı Arşivi (=B.O.A) Mühimme Defter No 6.

- Aksinia (Džurova), 1000 Godini Bălgarska răkopisna kniga, Ornament i Miniatyura, Sofia (Izd. Septemvri) 1981.

- Bistra (Cvetkova), "Sur le sort de Tărnovo", in: Byzantino-Bulgarica II, Sofia 19XX.

- Bistra A. Cvetkova - A. Razbojnikov (eds.) Izvori za Bâlgarskata Istoriya, III, Sofia (B.A.N.) 1972.

- Constantin (Jireček), Das Fürstenthum Bulgarien. Seine Bodengestaltung, Natur, Bevölkerung, Wirthschaftliche Zustände, geistige Cultur, Staatsverfassung, Staatsverwaltung und neueste Geschichte. (Bulgaria). Tempsky, Freytag,, Prag, Wien, Leipzig 1891.

- $\quad$ Djurdje (Bošković), Arhitektura Srednjeg Veka. Beograd 1967.

- $\quad$ Ekrem Hakkı (Ayverdi), Osmanlı Mimarî sinde Fatih Devri, III, 2. Bask1, Istanbul 1989.

- Emil (Turdeanu), La litterature bulgare du XIVe siècle et sa diffusion dans les pays roumains. Paris 1947.

- Eusebius (Fermendžiu), Acta Bulgariae Ecclesiastica ab A. 1565 ad A. 1799, Zagrabiae (Academia Scientiarum et Artium Slavorum Medianalium) 1887.

- Evgeni (Dermendžiev), "Dvortsovata banya na tărnovskite tsare", in: Izvestiya na Regionalen IstoričeskoMuzej-VelikoTărnovo XXII, 2007.

- Evgeni (Dermendžiev), "Novoodkrita banya južno ot tsrkvata Sv. 40 Mučenitsa văv Veliko Tărnovo", in: Stanislav Stanev, i al.(eds.) Izslevaniya v čest na Stefan Boyadžiev, Studies in honour of Stefan Boyadžiev, Sofia, B.A.N. 2011, pp. 77- 100.

- Halil (İnalcık) - Mevlûd (Oğuz), Gazavât-ı Sultân Murâd b. Mehemmed Hân: İzladi ve Varna (1443-1444) üzerinde anonim gazavâtnâme, Ankara: Türk Tarih Kurumu Yayınları, 1978.

- Herma M. van den (Berg), "Friesland”. Groningen. Drente (Kunstreisboek voor Nederland. dl. 2.). Unknown Binding 1958.

- İbnülemin Mahmud (İnal), Son Asır Türk Şairları, vol I, İstanbul: Devlet Kitapları 1969.

- Iliya (Zajčev), "Dva Arapski rukopisi is Tărnovo v Moskovskih Sobraniyah," in:

Obustovane s Istoku/Exchanges avec l'Orient, Mélanges offert à Stoyanka Kenderova, Rumen Kovačev - Boryana Hristova (eds.), Sofia (Nat. Library) 2007, pp. 420-423.

- Josiah Cox. Russell, "Die Bevölkerung Europas 500-1500”, in: Carlo M. Cipolla - Knud Borchardt, Bevölkerungsgeschichte Europas. München 1971, pp. 9-57.

- K. Škorpil, "Plan na starata bălgarska stolitsa V.Tărnovo", in: Izvestiya na Bălgarskoto Arheologičesko Družestva, I, Sofia 1910.

- Konstantin (Dočev), Moneti i obrăštenie v Tărnovo XII-XIV v. Veliko Tărnovo "Vital" 1992.

- Krasimira (Mutafova, "Središte na Islamskiya Mistitsizăm v Starata Stolitsa Tărnovo", in: Mjusjulmanskata Kultura po Bălgarskite Zemi, Sofia 1999, pp. 409 -450.

- Krăstju (Mijatev), Die Mittelalterliche Baukunst in Bulgarien. Sofia (BAN) 1974.

- $\quad$ Leon (Çika) - Ylli (Drishti), The Icons of Berat, Tirana 2009.

- Machiel (Kiel), "Zur Gründung und Frühgeschichte der Stadt Trjavna in Bulgarien. Unbenützte osmanische administrative Quellen aus den Archiven in Ankara, İstanbul und Sofia über Gründung und Entwicklung Trjavnas 1565-1700.“ In: Münchner Zeitschrift für Balkankunde, 7-8, (991), pp. 191-218.

- Murk Daniël (Ozinga), Kunstreisboek voor Nederland. chapter Groningen, Amsterdam 1954, pp. 79-115.

- Rogers J. (Mols), Introduction a la Démographie historique des villes d'Europe. Louvain 1955 (three volumes classic).

- 130 - $\mid$ Tirnovo ... Medieval Bulgarian capital to Turkish Islamic Cultural Centre 
- Sedat (Bayrakal), Edirne'deki tek kubbeli camiler, Ankara (T.C. Kültür Bakanlığı) 2001.

- Slobodan (Ćurčić), Architecture in the Balkans: From Diocletian to Süleyman the Magnificent. New Haven, CT: Yale University Press, 2010.

- Stefka (Părveva), "Zaviyeto Kavak Baba i čărkvata Sv. Četiridešet Măčenitsi”. in: Mjusjulmanskata Kultura po Bălgarskite Zemi, Sofia 1999, pp. 324 -408.

- Strašimir (Dimitrov), "Za datirovka na njakoj osmanski registri ot XV vek", in: Izvestiya na Bălgarskoto Istoričesko Družestvo, Knj. XXVI, 1968.

- Svetlin (Bosilkov), Tărnovo, gradăt i negovoto izkusstvo. Sofia 1960. (with survey of medieval history and rich documentation on the preserved monuments). Also: Svetlin (Bosilkov), Tarnovo, Die Stadt und ihre Kunst. Sofia 1960.

- T.D.E. Ansikl. Türk Dili ve Edebiyatı Ansiklopedisi, III, İstanbul: Dergah Yayınlar1 1979.

- Žečo (Čankov), Geografski Rečnik na Bălgariya, Sofia 1939.

- Zladka (Genova), "Ošte vednăž za tsărkvata Sv. Četirideset Măčenitsi i nejnata sădba prez stoletiyata na Osmansko vladičestvo", in: Rossitsa Gradeva (ed.) Mjusjulmanskata Kultura po Bălgarskite Zemi, Sofia 1999, pp. 451 -458. 